\title{
EFFECTIVENESS OF BIOREEF_BLOCK TECHNOLOGY ON REEF FISH DIVERSITY IN MARINE WATERS OF SUNGAI CUKA VILLAGE AT KINTAP DISTRICT, TANAH LAUT REGENCY OF SOUTH KALIMANTAN, INDONESIA
}

\author{
Tony Frans ${ }^{1 *}$, Iskandar Rina ${ }^{2}$, Rifa'l M. Ahsin ${ }^{1}$, Khasanah Ruly Isfatul $^{3}$ \\ ${ }^{1}$ Department of Marine Science, Faculty of Fisheries and Marine Science, \\ University of Lambung Mangkurat, South Kalimantan, Indonesia \\ ${ }^{2}$ Department of Fisheries, Faculty of Agriculture, University of Achmad Yani Banjarmasin, \\ South Kalimantan, Indonesia \\ ${ }^{3}$ Marine Science Program, Faculty of Science and Technology, State Islamic University \\ of Sunan Ampel, Surabaya, Indonesia \\ *E-mail: ftony@ulm.ac.id
}

\begin{abstract}
Bioreef_Block is a modified blend of Bioreeftek with concrete blocks. Bioreef_Block is a medium that uses green technology that utilizes natural materials (coconut shells) which aims as a medium for the attachment of coral planula larvae, with a concrete block foundation in the form of a hollow cube frame with the aim of providing a fish house. This study aims to determine the effectiveness of Bioreef_Block technology on the diversity of reef fish in the sea waters of Sungai Cuka Village, Kintap District, Tanah Laut Regency, South Kalimantan, Indonesia. From the physical and chemical parameters of the water, only the salinity is below the quality standard, this is presumably due to high rainfall. From this study it can be concluded that in general the number of families recorded is 13 families with 18 species of fish found in the vicinity of Bioreef_Block. The composition of the target fish group was 10 families while the major and indicator fish were 2 families, there was an increase in fish abundance at each data collection, the value of the diversity index $\left(\mathrm{H}^{\prime}\right)$ was small with very strong environmental pressure, but in each observation there was an increase in diversity. The uniformity index (E) before the presence of Bioreef_Block was small with a depressed community, but after the presence of Bioreef_Block in the first month there was a moderate increase in uniformity, with unstable communities, and in the following month observations there was high uniformity with stable communities. Meanwhile, for the dominance index $(C)$ of reef fish, there are no criteria for dominant fish.
\end{abstract}

\section{KEY WORDS}

Bioreef_Block, coral fish, Sei Water, Sungai Cuka, Kintap, South Kalimantan.

Reef fish are important communities in coral reef ecosystems because of their trophic relationship with other biotic components (Tony. F, et al 2021, Rifa'i, 2016; Rifa'i, et al, 2016).

Bioreef_Block is a modification of the combination of Bioreeftek with concrete blocks where Bioreeftek is a new technique for making artificial reefs naturally, because it uses materials from nature such as coconut shells to attract planula (Ampou, 2011), while concrete blocks in the form of a cube frame serve as a hollow foundation. cavity with the aim of providing fish houses so that Bioreef_Block is a green technology medium that utilizes natural materials (coconut shells) which aims as a medium for attaching coral planula larvae, with a concrete block foundation in the form of a hollow cube frame with the aim of providing fish houses.

Healthy coral reef ecosystems store the value of reef and fish biodiversity. Fish are one of the biotic components in coral reef ecosystems and fill very specific microhabitats of coral reefs (Messmer et al. 2011; Coker et al. 2013; Komyakova et al. 2018).

Coral reef ecosystems around the sea waters of Sei Cukka Kec. Kintap found only 1 type of Acropora coral lifeform, namely Acropora tabulate (ACT), and 4 non-Acropora species namely Coral branching (CB), Coral massive (CM), Coral encrusting (CE), Coral foliose (CF). The coverage range of live coral reefs ranged from $1.88 \%$ to $46.38 \%$. 
Therefore, the condition of coral reefs around the sea waters of Sei Cuka Kec. Kintap ranges from poor to moderate based on coral reef assessment criteria according to KEPMEN LH No. 4 Th. 2011 (Tony. F, et al 2020).

In 2021 PT. Arutmin Indonesia Kintap Mine, South Kalimantan has attempted to restore coral reefs and reef fish using the bioreef_block method, namely the application of green technology that utilizes natural materials (coconut shells) which aims as a medium for attaching coral planula larvae, with a hollow concrete block foundation. -a cavity with the aim of providing a fish house (Tony. F, 2021)

Reef fish are one of the groups of animals associated with coral reefs, their presence is conspicuous and found in various micro-habitats on coral reefs. Reef fish live permanently and forage in coral reef areas (sedentary), so that if coral reefs are damaged or destroyed, reef fish will also lose their habitat (Rani et al., 2010). With this background, it is deemed necessary to conduct research to determine the effectiveness of Bioreef_Block technology on the diversity of reef fish in the sea waters of Sungai Cuka Village, Kintap District, Tanah Laut Regency, South Kalimantan, with the government's very important role in managing the utilization of coastal potential and empowering coastal village communities to support development diversify their business (Hidayat A. S., and Agusliani, E., 2020).

\section{METHODS OF RESEARCH}

The material from this research is reef fish that are found around the bioreef block in the sea waters of Sungai Cuka Village, Kintap District, Tanah Laut Regency, South Kalimantan Province. The research station is set as many as 20 sets of Bioreef_Block which are located in the sea waters of Sungai Cuka Village, Kintap District, Tanah Laut Regency, South Kalimantan Province. As a description of bioreef_block can be seen in Figure 1 below:
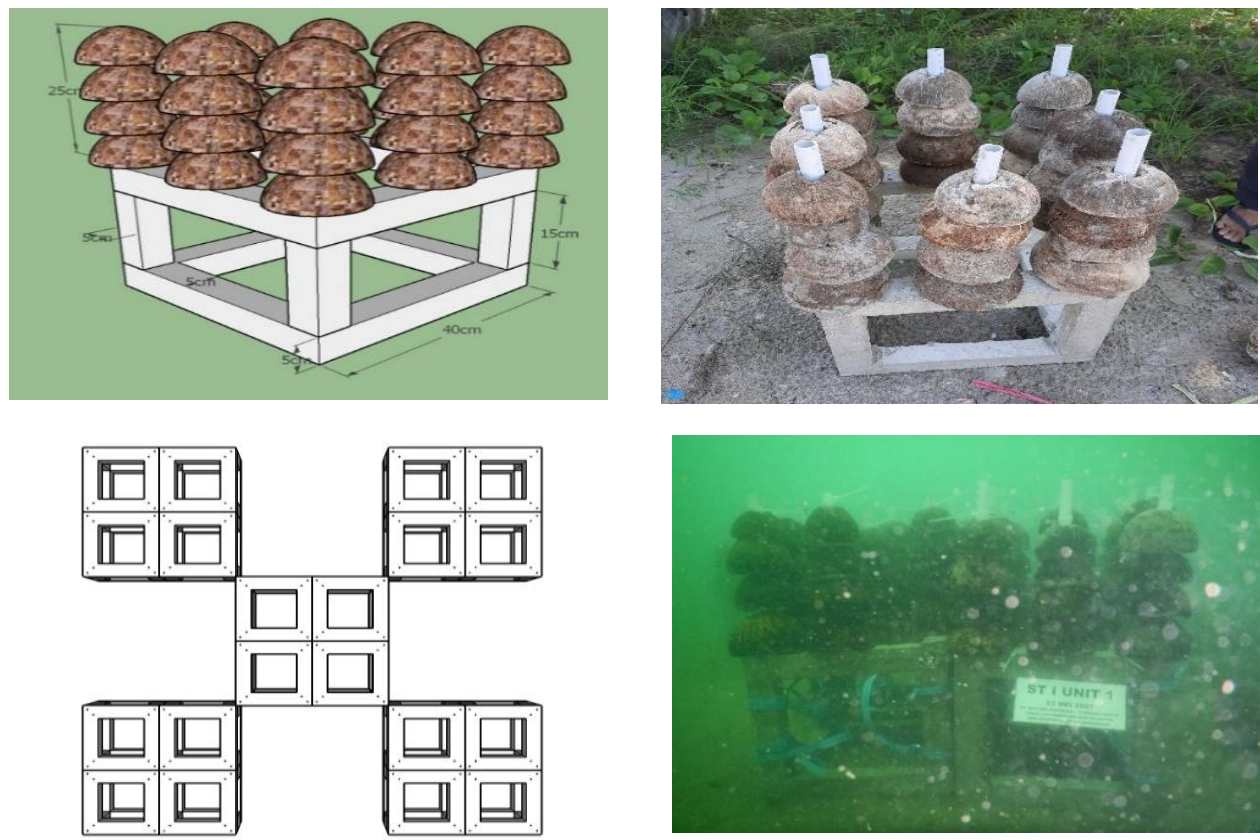

Figure 1 - Bioreef_Block

Reef fish data was obtained by stationary visual observation method, the reef fish data logger observed 20 sets of Bioreef_Blocks placed close together for 5-10 minutes each while recording all fish species and their abundance. Data collection was carried out around Bioreef_Block with a distance of \pm 2.5 meters from the outermost Bioreef_Block for 3 (three) observations for 3 months, namely in April 2021 before placing Biereef_Block, May 2021 after 1 month of placing and June 2021 after 2 months of placing it. Reef fish species that cannot be identified directly by the researcher are written down on the slate board or by 
photographing and recording observations using an underwater camera that has been set to video mode and then the results are identified using the identification key book from Kuiter (1992). The balance of the reef fish community is seen based on its community structure with the approach of calculating the diversity index, uniformity index and dominance index. As supporting data, several physical and chemical environmental parameters were also measured in the form of current velocity ( $\mathrm{m} / \mathrm{s}$ by current meter), brightness ( $\mathrm{m}$ by Sechi disk), temperature $\left({ }^{0} \mathrm{C}\right), \mathrm{pH}(\mathrm{pH}$ meter), salinity (\%o) and dissolved oxygen ( $\mathrm{mg} / \mathrm{L}$ by DO meter).

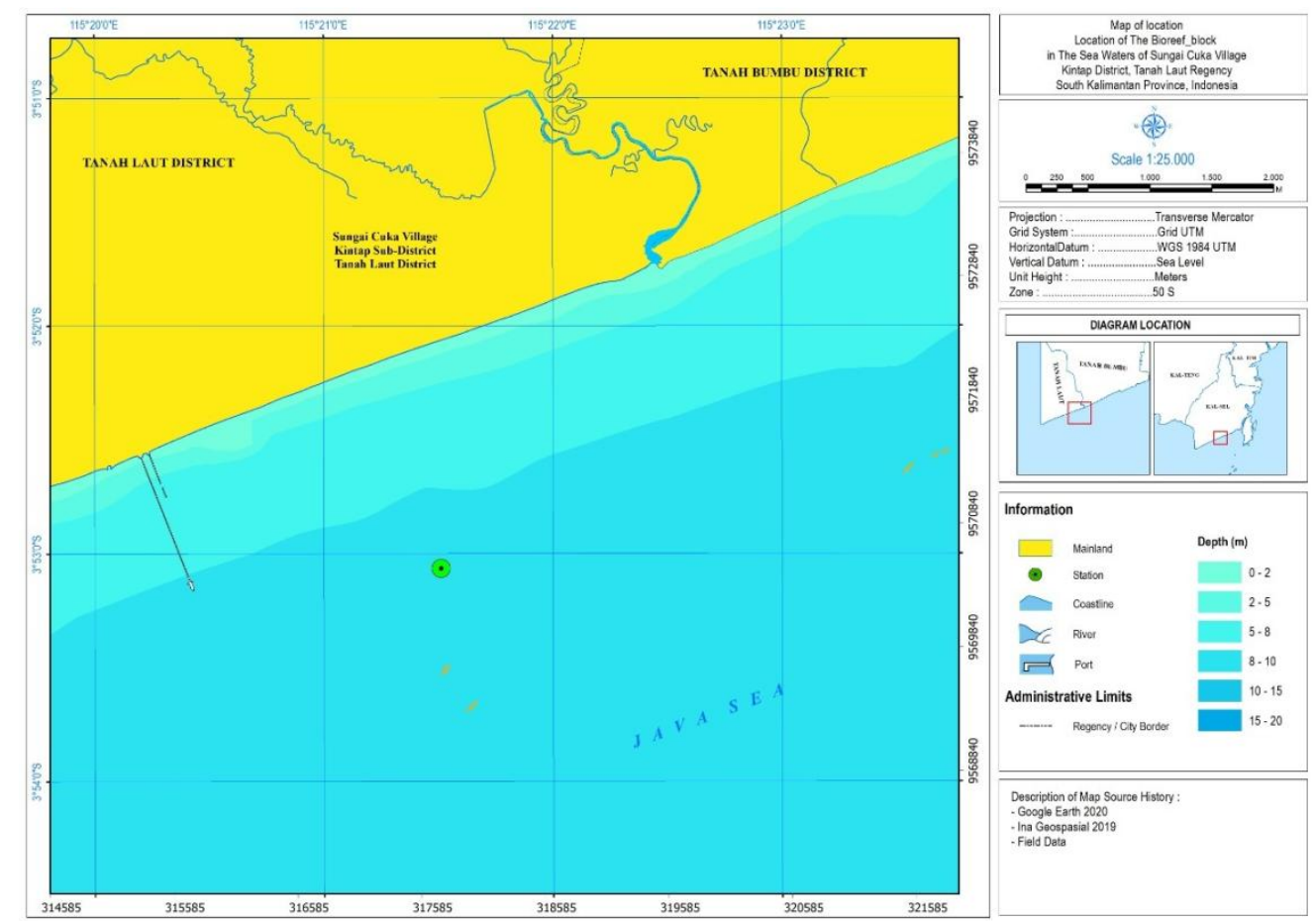

Figure 2 - Location Map where Bioreef_Block is placed in the sea waters of Sei Village, Cuka, Kintap District, Tanah Laut Regency, South Klaimantan Province

Abundance of coral reef fishes was calculated using the equation below (English et al., 1994):

$$
N=\frac{n i}{A}
$$

Where: $N$ is fish abundancy (ind $/ \mathrm{m}$ ); $n i$ is individual number No-l; and $A$ is area width $\left(\mathrm{m}^{2}\right)$.

Diversity index was calculated by criteria according to Brower \& Zar (1977):

$$
H^{\prime}=\sum_{i=1}^{s} p i \ln p i
$$

Where: $H^{\prime}$ = Diversity index; $\mathrm{S}=$ Coral reef fish species number; $\mathrm{p}=$ Individual number proportion of coral reef fish species.

a. $H^{\prime} \leq 2,30$ : diversity is low, environment pressure is very strong;

b. $2.30<\mathrm{H}^{\prime} \leq 3,30$ : diversity is moderate, environment pressure is moderate;

c. $H^{\prime}>3,30$ : diversity is high, ecosystem balance occurs.

The index of reef fish uniformity was calculated using the equation below:

$$
\mathrm{E}=\frac{\mathrm{H}^{\prime}}{\mathrm{Hmax}}
$$

Where: $\mathrm{E}=$ Uniformity index; $\mathrm{Hmax}=$ Species balance in maximum balance $=$ In $\mathrm{s}$. 
Index values ranged from 0-1 with criteria (Brower \& Zar 1977):

- $E \leq 0,4$ : uniformity is low, community is pressured;

- $0,4<\mathrm{E} \leq 0,6$ : uniformity is moderate, community is unstable;

- $E>0,6$ : uniformity is high, community is stable.

Dominance index of coral reef fish is calculated using the equation below:

$$
C=\sum_{i=1}^{s} p i^{2}
$$

Where: $\mathrm{C}=$ dominance index; $\mathrm{Pi}=$ individual number proportion on coral reef fish; $\mathrm{S}=$ species number of coral reef fish.

The dominance index value ranged from 1 to 0 which meant that if the value approached 1 then there was a tendency for one individual to dominate another. As for the large percentage of live coral cover, dead coral, and other types of lifeform calculated using the formula (English et al, 1997):

$$
\mathrm{C}=\frac{\alpha}{A} \times 100 \%
$$

Where: $\mathrm{C}=$ lifeform $i$ coverage percentage; $\alpha=$ lifeform $i$ transect length; $\mathrm{A}=$ transect total length.

\section{RESULTS AND DISCUSSION}

Based on the results of the study, in general the number of families recorded was 13 families with 18 species of reef fish from a total of 1,383 individuals scattered around Bioreef_Block for 3 (three) observations, namely in May 2021 before placing Biereef_Block, June 2021 after 1 month. placed and July 2021 after 2 months placed.

Table 1 - Abundance of Coral Fish Based on Family, Species and Number of Coral Reef Fish

\begin{tabular}{lll}
\hline FAMILY NAMES and FISH SPECIES & SPECIES NUMBER & INDIVIDUAL NUMBER \\
\hline Major & 2 & 562 \\
\hline POMACENTRIDAE & 1 & 135 \\
Target & 1 & 1 \\
CAESIONIDAE & 1 & 1 \\
CARANGIDAE & 1 & 7 \\
DIODONTIDAE & 2 & 215 \\
EPHIPPIDAE & 2 & 206 \\
LUTJANIDAE & 1 & 35 \\
HAEMULIDAE & 2 & 152 \\
HOLOCENTRIDAE & 1 & 27 \\
NEMIPTERIDAE & 1 & 1 \\
SERRANIDAE & & 30 \\
SCYLIORHINIDAE & 2 & 11 \\
Indicator & 1 & 1.383 \\
CHAETODONTIDAE & 18 & \\
POMACANTHIDAE & & \\
\hline Total & &
\end{tabular}

The most fish compositions are from the POMACENTRIDAE (2 Species with 562 Individuals), LUTJANIDAE (2 Species with 215 Individuals), HAEMULIDAE (2 Species with 206 Individuals), NEMIPTERIDAE (2 Species with 152 Individuals), HOLOCENTRIDAE (2 Species with 35 Individuals), CHAETODONTHIDAE (2 Species with 30 Individuals), SERRANIDAE (1 Species with 27 Individuals), POMACANTHIDAE (1 Species with 11 Individuals), EPHIPPIDEE (1 Species with 7 Individuals) and CARANGIDAE, DIODONTIDEE , SCYLIORHINIDAE with 1 Species and Individuals each. Of all the fish families found at the study site, there were 7 similar families from 19 families which were also found on Halang Melingkau Island, Kotabaru Regency, South Kalimantan Province, namely POMACENTRIDAE, CHAETODONTHIDAE, HAEMULIDAE, LUTJANIDAE, SERRANIDAE, HOLOCENTRIDAE, and POMACANTHIDAE (Tony F. et al, 2021). 

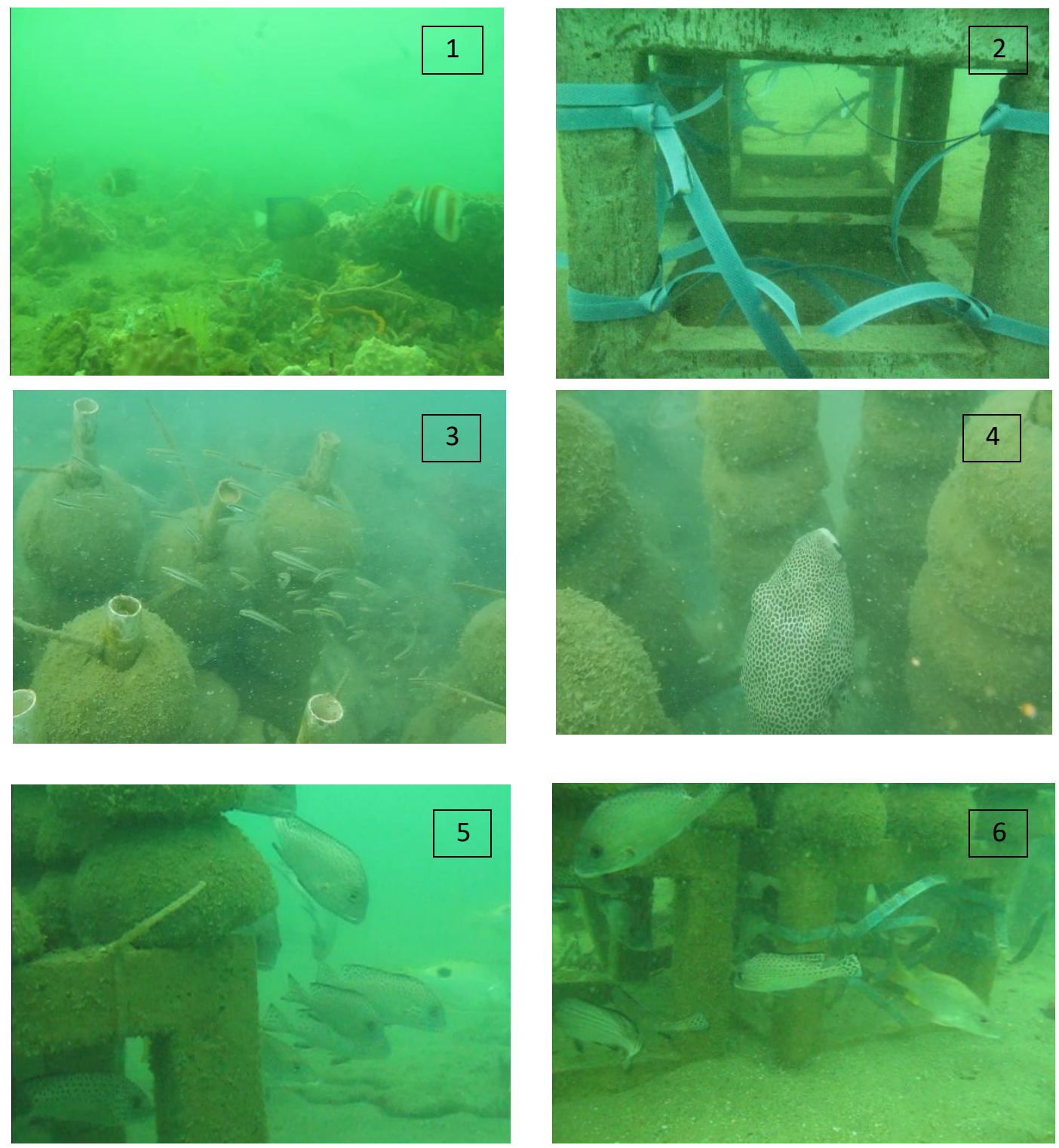

Figure 3 - The condition of the Bioreef_Block after 2 months of being placed (1). Before placing Bioreeb_Block, (2) the presence of Bioreef_Block in the waters (3) There are small fish around Bioreef_Block., (4) Diodon hystrix is between coconut shells., (5 and 6) Fish are around Bioreef_Block

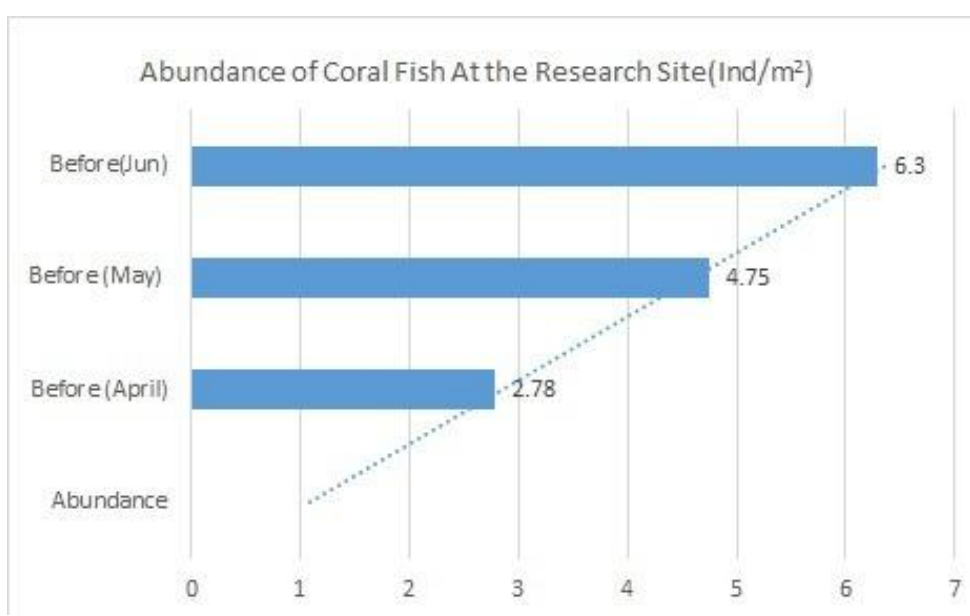

Figure 4 - Fish abundance around Bioreef_Block $\left(\operatorname{Ind} / \mathrm{m}^{2}\right)$ 
Results of this study, it can be concluded that the abundance of fish in the Bioreef_Block from before placing the Bioreef_Block until 2 months after being placed there was an increase in abundance, which can be seen in Figure 3 while the abundance of individuals can be seen in Figure 4 and for diversity and abundance during the study, it can be seen in Table 2.

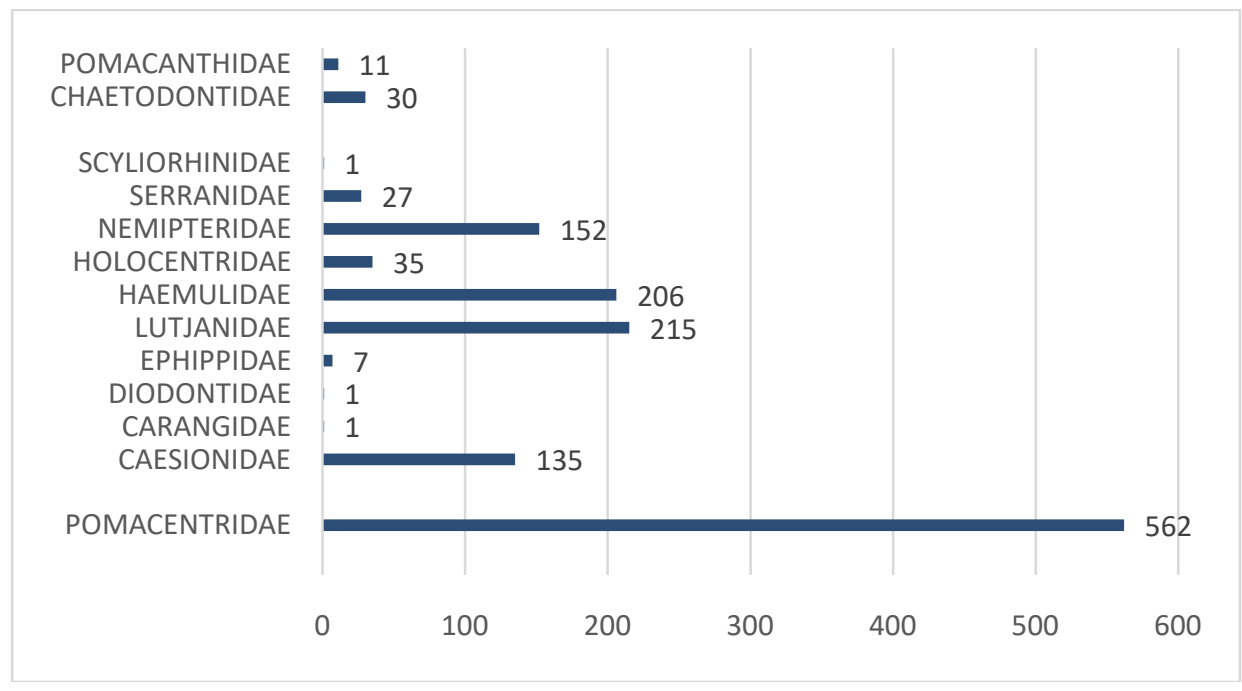

Figure 5 - Individual abundance during the study

Table 2 - Diversity and abundance of fish during the study

\begin{tabular}{|c|c|c|c|c|c|}
\hline Family & Species & April & May & June & Total \\
\hline \multicolumn{6}{|l|}{ Major } \\
\hline \multirow[t]{2}{*}{ POMACENTRIDAE } & Chrysiptera parasema & 73 & 78 & 100 & 251 \\
\hline & Plectroglyphidodon imparipennis & 83 & 98 & 130 & 311 \\
\hline \multicolumn{6}{|l|}{ Target } \\
\hline CAESIONIDAE & Caeseo teres & 18 & 47 & 70 & 135 \\
\hline CARANGIDAE & Caranx ignobilis * & & & 1 & 1 \\
\hline DIODONTIDAE & Diodon hystrix * & & & 1 & 1 \\
\hline EPHIPPIDAE & Platax boersii (Golden Spadefis - Juvenile ) * & & & 7 & 7 \\
\hline \multirow[t]{2}{*}{ LUTJANIDAE } & Lutjanus ehrenbergi & 38 & 72 & 90 & 200 \\
\hline & Lutjanus sebae * & & & 15 & 15 \\
\hline \multirow[t]{2}{*}{ HAEMULIDAE } & Diagrama melacrum & 27 & 47 & 50 & 124 \\
\hline & Plectorhincus picus & 15 & 17 & 50 & 82 \\
\hline HOLOCENTRIDAE & Sargocentron cornotum & & 35 & & 35 \\
\hline \multirow{2}{*}{ NEMIPTERIDAE } & scolopsis auratus & 16 & 26 & 50 & 92 \\
\hline & Scolopsis vosmeri & 5 & 15 & 40 & 60 \\
\hline SERRANIDAE & Cephalopholis formosa & & 27 & & 27 \\
\hline SCYLIORHINIDAE & Atelomycterus marmoratus * & & & 1 & 1 \\
\hline \multicolumn{6}{|l|}{ Indicator } \\
\hline \multirow[t]{2}{*}{ CHAETODONTIDAE } & Coradion chrysozonus & 3 & 6 & 10 & 19 \\
\hline & Chelmon rastratus & & 3 & 8 & 11 \\
\hline POMACENTRIDAE & Pomacanthus annularis & & 4 & 7 & 11 \\
\hline \multicolumn{2}{|c|}{ Total Individual } & 278 & 475 & 630 & 1383 \\
\hline \multicolumn{2}{|c|}{ Total Species Per Observation } & 9 & 13 & 16 & 18 \\
\hline \multicolumn{2}{|c|}{ Total Number of Species } & 18 & & & \\
\hline
\end{tabular}

As for the results of this study, the values of the Diversity Index $\left(\mathrm{H}^{\prime}\right)$, the uniformity index $\left(E^{\prime}\right)$ and the dominance index $(C)$ of reef fish can be seen in Figure 6 below;

Based on the value of the diversity index $\left(\mathrm{H}^{\prime}\right)$, at the research site there is a small diversity, with very strong environmental pressures, but every observation there is an increase in diversity. For the uniformity index $(\mathrm{E})$ before the presence of Bioreef_Block the uniformity was small with depressed communities, but after the presence of Bioreef_Block in the first month there was a moderate increase in uniformity, with unstable communities, and in the observation the following month (2nd month observation) there was a high uniformity with a stable community. Meanwhile, for the dominance index (C) of reef fish, 
there is no criteria for dominant fish. The values and criteria for the uniformity index $\left(\mathrm{H}^{\prime}\right)$, uniformity index ( $\left.E^{\prime}\right)$ and dominance index $(C)$ of reef fish can be seen in Table 3 below.

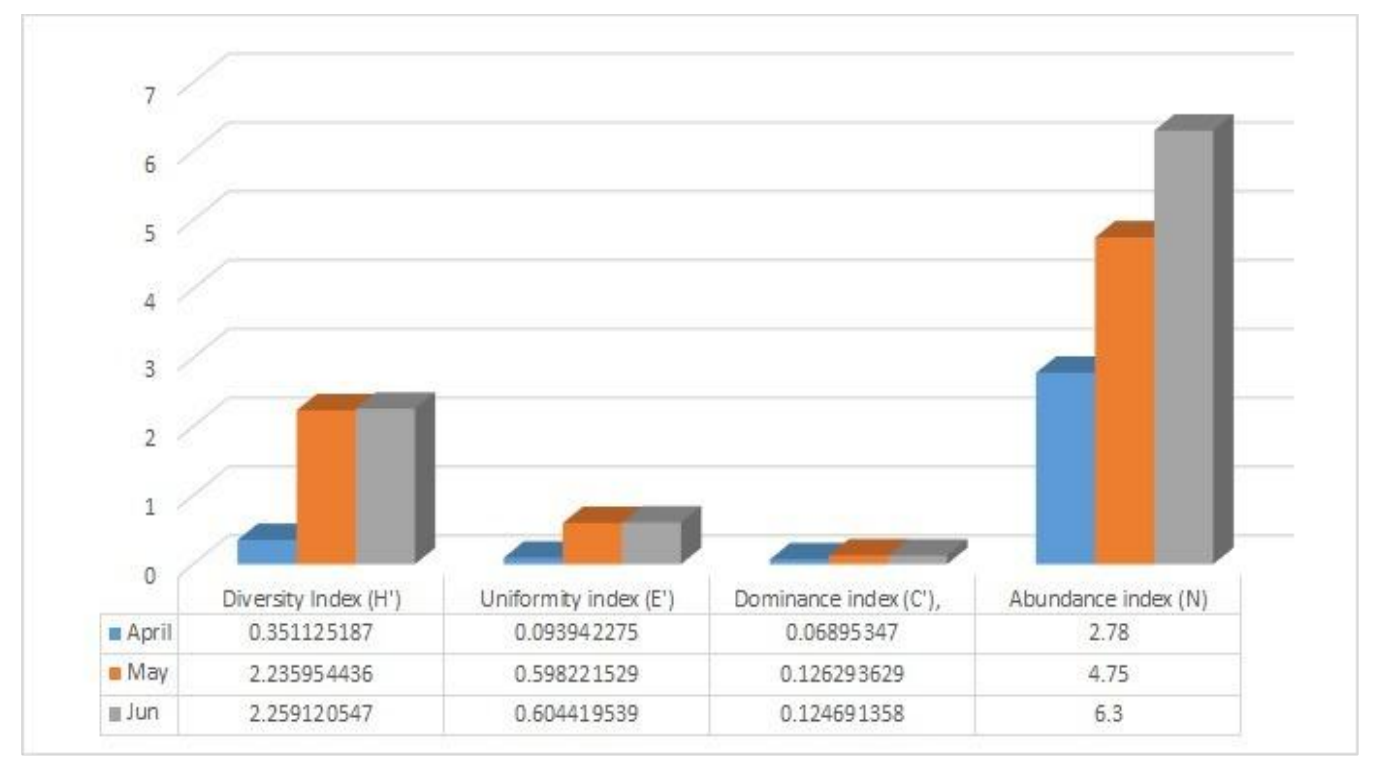

Figure 6 - Value of diversity index $\left(\mathrm{H}^{\prime}\right)$, uniformity index $\left(\mathrm{E}^{\prime}\right)$ and dominance index $(\mathrm{C})$ of reef fish

Table 3 - Index values and criteria for Diversity, Uniformity and Dominance of fish around Bioreef_Block in the waters of the research location

\begin{tabular}{|c|c|c|c|c|c|c|}
\hline \multirow{3}{*}{ Observation Time } & \multicolumn{6}{|l|}{ Index } \\
\hline & \multicolumn{2}{|l|}{ Diversity } & \multicolumn{2}{|l|}{ Uniformity } & \multicolumn{2}{|l|}{ Dominance } \\
\hline & Value $\left(\mathrm{H}^{\prime}\right)$ & Criteria & Value (E) & Criteria & Value (C) & Criteria \\
\hline $\begin{array}{l}\text { April } \\
\text { (Before there was } \\
\text { Bioreef_Block) }\end{array}$ & 0.35 & $\begin{array}{l}\text { small diversity, very } \\
\text { strong environmental } \\
\text { pressure }\end{array}$ & 0.09 & $\begin{array}{l}\text { Small } \\
\text { uniformity, } \\
\text { depressed } \\
\text { community }\end{array}$ & 0.06 & $\begin{array}{l}\text { No one } \\
\text { dominates }\end{array}$ \\
\hline $\begin{array}{l}\text { May } \\
\text { (After } \\
\text { Bioreef_Block) }\end{array}$ & 2.23 & $\begin{array}{l}\text { small diversity, very } \\
\text { strong environmental } \\
\text { pressure }\end{array}$ & 0.59 & $\begin{array}{l}\text { Moderate } \\
\text { uniformity, } \\
\text { unstable } \\
\text { community }\end{array}$ & 0.12 & $\begin{array}{l}\text { No one } \\
\text { dominates }\end{array}$ \\
\hline $\begin{array}{l}\text { June } \\
\text { (After } \\
\text { Bioreef_Block) }\end{array}$ & 2.25 & $\begin{array}{l}\text { small diversity, very } \\
\text { strong environmental } \\
\text { pressure }\end{array}$ & 0.60 & $\begin{array}{l}\text { High uniformity, } \\
\text { stable } \\
\text { community }\end{array}$ & 0.12 & $\begin{array}{l}\text { No one } \\
\text { dominates }\end{array}$ \\
\hline
\end{tabular}

The sea waters in Sungai Cuka Village, Kintap District, Tanah Laut Regency, South Kalimantan Province with a sand base and coral reefs which are mostly live coral with quality based on data obtained from data collection at the location where the bioreef_Block is placed during monthly observations from April to June seen in Table 4.

Table 4 - Index Value and Criteria for Diversity, Uniformity and Dominance of fish around Bioreef_Block in the waters of the research location

\begin{tabular}{|c|c|c|c|c|c|c|c|c|}
\hline \multirow[b]{2}{*}{$\begin{array}{l}\text { Bioreef_Block } \\
\text { Coordinates }\end{array}$} & \multirow{2}{*}{ Location } & \multirow[b]{2}{*}{$\begin{array}{l}\text { Observation } \\
\text { time }\end{array}$} & \multicolumn{3}{|c|}{ Physical Factor } & \multicolumn{3}{|c|}{ Chemical Factor } \\
\hline & & & $\begin{array}{l}\text { Temp } \\
\left({ }^{\circ} \mathrm{C}\right)\end{array}$ & $\begin{array}{l}\text { Bright } \\
\text { (m) }\end{array}$ & $\begin{array}{l}\text { Current } \\
(\mathrm{m} / \mathrm{s})\end{array}$ & $\begin{array}{l}\text { Salinity } \\
(\%)\end{array}$ & $\mathrm{pH}$ & $\mathrm{DO}(\mathrm{mg} / \mathrm{l})$ \\
\hline \multirow{3}{*}{\multicolumn{2}{|c|}{$\begin{array}{l}\text { S } 03^{0} 53^{\prime} 3,88^{\prime \prime} \\
\text { E } 115^{0} 21^{\prime} 30,93^{\prime \prime}\end{array}$}} & Aril & 30.3 & 1.6 & 0.19 & 27.2 & 7.09 & 5.6 \\
\hline & & May & 29.8 & 1.55 & 0.23 & 26.5 & 6.63 & 5.3 \\
\hline & & June & 30.3 & 2.5 & 0.20 & 27.2 & 7.43 & 5.6 \\
\hline \multicolumn{3}{|c|}{ Kepmen LH No 51, 2004} & $28-30^{\circ} \mathrm{C}$ & $>5$ & & $33-34$ & $7-8.5$ & $>5$ \\
\hline
\end{tabular}

Temperature is one of the parameters of environmental factors that affect organisms in metabolic activities, breeding and physiological processes of organisms because temperature can affect the physical, chemical and biological properties of waters (Febrizal et 
al., 2009). The water temperature conditions at the time of the study ranged from $29.80 \mathrm{C}$ to $30.3 \mathrm{0C}$. If viewed from the temperature range based on the quality standard for seawater biota according to the Minister of Environment Decree No. 51 of 2004, which ranges from 28 $-30{ }^{\circ} \mathrm{C}$, it is known that the temperature of these waters is in the normal range that meets the requirements for the survival of coral fish or is in the normal range. range of quality standard thresholds for seawater biota.

The brightness at the research site does not penetrate the bottom of the water with a depth of 6 meters. As a result, light entering the water can only penetrate to a certain depth, which is between $1.6-2.5$ meters, before the light is completely absorbed, thus most of the volume of water in the ocean is without light. Brightness is a measure of water transparency, which is found visually using a secchi disk with a brightness value expressed in meters, this value is strongly influenced by weather conditions, measurement time, turbidity and suspended solids. The absorption of light by water varies greatly depending on the wavelength. As a result, certain wavelengths penetrate more deeply than others (Nybakken, 1992).

At the study site the velocity of the water current ranged from 0.19 to $0.23 \mathrm{~m} / \mathrm{s}$ (Table 4). The speed of this current is in line with the waters of Halang Melingkau Island, Kotabaru Regency, which ranges from 0.04 to 0.21 which was taken in the same season, namely the west wind season, namely in March 2019 (Tony, F., et al., 2020) but is larger than those in the coastal waters of Angsana Subdistrict, Tanah Bumbu, South Kalimantan Province in January 2013 which ranged from $0.01-0.05 \mathrm{~m} / \mathrm{s}$ with an average of $0.03 \mathrm{~m} / \mathrm{s}$ (Iskandar and Tony, 2013). The highest measured current speed is in May and the lowest is in April. These results indicate that water currents are not the main factor affecting the abundance of fish around the Bioreef_Block in the research location. Current is one of the factors that limit the spread of aquatic organisms such as fish whose life moves against the current. The current range at the research location is included in the above normal range according to Yusuf et al., 2012 which is only around $0.309 \mathrm{~m} / \mathrm{s}$ with an average of $0.055 \mathrm{~m} / \mathrm{s}$. But according to Sekerci and Petrovskii 2015; Basu and Mackey 2018 Water currents play a role in the growth process of food supply in the form of plankton and oxygen. Currents carry oxygen, zooplankton, and nutrients needed for corals as the main habitat for reef fish (Hamner et al. 2007).

According to Kültz (2015) and Lehtonen et al (2016), salinity has an important role that is closely related to the life of aquatic organisms including fish. Coral reefs and related biota, including reef fish, have a limited ability to tolerate changes in salinity in the range of 25 to $40 \%$ (Smyth and Elliott 2016) while salinity values at the study site ranged from $26.5-27.2$. The low salinity in these waters is suspected at the time of collecting salinity data, at night there has been rain so it is suspected that rainwater and water from the mainland through the Sungai Cuka have affected the salinity. However, according to Effendi (2003) the normal category for marine life is that the salinity value of the waters ranges from $30-40 \%$. In this study, the $\mathrm{pH}$ of the water was in the range of 6.63 to 7.43 so that when referring to the Decree of the Minister of the Environment No. 51 of 2004, the Republic of Indonesia, the best acidity $(\mathrm{pH})$ of sea water for marine biota, including reef fish, is between 7.0 and 8.5. Generally, the $\mathrm{pH}$ of seawater does not vary much because the carbon dioxide system in the water has a strong buffer capacity (Feely et al. 2009; Putri et al. 2015).

DO (Dissolved Oxygen) is one of the limiting factors for the life of organisms. Changes in dissolved oxygen concentration can have a direct effect resulting in the death of aquatic organisms. According to Faturohman et al (2016), water with a DO value of less than $3 \mathrm{mg} / \mathrm{L}$ will cause the death of aquatic organisms. DO in the water in this study showed a range between $5.3-5.6 \mathrm{mg} / \mathrm{l}$. These results are in line with observations made in the southern waters of Pulau Laut Village, Teluk Tamiang, Pulau Laut Tanjung Selayar District, Kotabaru Regency, South Kalimantan Province, which ranged from 5.8 to $10.8 \mathrm{mg} / \mathrm{L}$ (Sahril 2017). The waters of Halang Melingkau Island DO reach 9.00-9.88 mg/L, (Tony, F., Soemarno, Wiadnya, D, G, R., Hakim, L. 2020). Based on the Decree of the State Minister of the Environment Number 51 of 2004 , it is stated that the DO quality standard value for marine biota is $>5 \mathrm{mg} / \mathrm{l}$. The results of measurements at the research site indicate that the DO 
content is still within the threshold that meets the quality standard for marine biota. However, there is an indirect effect, namely increasing the toxicity of pollutants which can ultimately harm the organism itself (Rahayu, 1991).

\section{CONCLUSION}

From this research, it can be concluded that in general the number of families recorded is 13 families with 18 fish species found around Bioreef_Block. The composition of the target fish group was 10 families while the major and indicator fish were 2 families.

There is an increase in fish abundance, the value of the diversity index ( $\left.\mathrm{H}^{\prime}\right)$ is small with very strong environmental pressures, but every observation there is an increase in diversity. For the uniformity index (E) before the presence of Bioreef_Block the uniformity was small with depressed communities, but after the presence of Bioreef_Block in the first month there was a moderate increase in uniformity, with unstable communities, and in the following month observations there was high uniformity with stable communities. Meanwhile, for the dominance index $(\mathrm{C})$ of reef fish, there is no criteria for dominant fish.

\section{ACKNOWLEDGMENTS}

The author expresses his gratitude to PT. Arutmin Indonesia Kintap Mine, Kintap District, Tanah Laut Regency, South Kalimantan Province, which supported and facilitated this research. The author would also like to thank the Dean of the Faculty of Fisheries and Marine Affairs, Lambung Mangkurat University, Ahmad Yani University, State Islamic University of Sunan Ampel, the local government of Tanah Laut Regency, Indonesia, as well as all friends who have supported so that this research can be completed.

\section{REFERENCES}

1. Ampou, Elvan. E (2011). Bioreeftek. Tim Perubahan Iklim (climate change), Balai Penelitian and Observasi Laut (BPOL) Kementerian Kelautan and Perikanan Bali. Jembrana, Bali.

2. Basu S, Mackey KRM. 2018. Phytoplankton as key mediators of the biological carbon pump: Their responses to a changing climate. Sustainability 10: 1-18.

3. Brower, J. E., and Zar, J. H., 1977. Fild and Laboratory Method for General Ecologi. 151156. Wm. C Brown Publishing Dubuque. lowa

4. English, S., Wilkinson, C., Baker,V,. 1994. Survey Manual For Tropical MarineResources. ASEAN - Australia Marine Science Project Living CoastalResources. Australia.

5. Faturohman I, Sunarto, Nurruhwati I. 2016. The correlation of plankton abundance with seawater temperature at Cirebon steam electricity power station. Jurnal Perikanan Kelautan VII: 115-122. [Indonesian]

6. Febrizal, Damar A, Zamani NP. 2009. Kondisi Ekosistem Terumbu Karang di Perairan Kabupaten Bintan and Alternatif Pengelolaannya. Jurnal IImu-ilmu Perairan and Perikanan Indonesia. 2: 167-175

7. Feely RA, Orr J, Fabry VJ, Kleypas JA, Sabine CL, Langdon C. 2009. Present and future changes in seawater chemistry due to ocean acidification. Geophys Monogr Ser 183: 175-188.

8. Habitat Biodiversity as a Determinant of Fish Community Structure on Coral Reefs in Halang Melingkau Island, Kotabaru, South Kalimantan, Indonesia. Egyptian Journal of Aquatic Biology \& Fisheries Zoology Department, Faculty of Science, Ain Shams University, Cairo, Egypt. ISSN 1110 - 6131 Vol. 25(1): 351 - 370 (2021).

9. Hamner WM, Colin PL, Hamner PP. 2007. Export-import dynamics of zooplankton on a coral reef in Palau. Mar Ecol Prog Ser 334: 83-92.

10. Hidayat A. S., and Agusliani, E., 2020. Beach tourism, whether benefit or disaster for coastal fishermen of Tanah Laut Regency, South Kalimantan Province. AACL Bioflux, 2020, Volume 13, Issue 3. 
11. Herawati, E. Y. Maziyyah, S. Munir, M. Perdanawati, R, A. Khasanah, R, I. 2021. Relationship between coral fish community structure and coral cover in Paiton Waters, Probolinggo-East Java, Indonesia. AACL Bioflux, 2021, Volume 14, Issue 3. P 12131221.

12. Iskandar. R, Tony F., 2013. Sedimentation study at Angsana River in Angsana Subdistrict, Tanah Bumbu District, South Kalimantan. Enviro Scienteae 9: 106-111. [Indonesian]

13. [KepMen LH] Keputusan Menteri Lingkungan Hidup. 2004. Keputusan Menteri Negara Lingkungan Hidup Nomor 51 Tahun 2004 Tentang Baku Mutu Air Laut. Jakarta: Kementerian Lingkungan Hidup press.

14. Khasanah R. I., Herawati E. Y., Hariati A. M., Mahmudi M., Sartimbul. A, Wiadnya. D, G. R, Asrial. E, Yudatomo, Nabil, E. 2019. Growth rate of Acropora formosa coral fragments transplanted on different composition of faba kerbstone artificial reef. BIODIVERSITAS. Volume 20, Number 12. Pages: 3593-3598

15. Khasanah R. I., Herawati E. Y., Hariati A. M., Mahmudi M., 2020 Growth rate and survivorship of Acropora sp. fragments that transplanted on the artificial substrate made from fly ash and bottom ash. IOP Conference Series: Earth and Environmental Science 441:012126.

16. Kuiter RH. 1992. Tropical Reef Fish of Western Pacific. Indonesia and Adjacent Waters. PT. Gramedia Pustaka Utama, Jakarta

17. Kültz D. 2015. Physiological mechanisms used by fish to cope with salinity stress. J Exp Biol 218: 1907-1914.

18. Lehtonen TK, Wong BBM, Kvarnemo C. 2016. Effects of salinity on nest-building behaviour in a marine fish. BMC Ecol 16. DOI: 10.1186/s12898-016-0067-y

19. Nybakken, J.W. 1992. Biologi Laut Suatu Pendekatan Ekologi. PT Gramedia Pustaka Utama, Jakarta.

20. Putri MR, Setiawan A, Safitri M. 2015. Variation of ocean $\mathrm{pH}$ in the Indonesia waters. AIP Conf Proc 1677: 060021. DOI: 10.1063/1.4930701.

21. Rahayu S, 1991. Penelitian Kadar Oksigen Terlarut (DO) dalam Air bagi Kehidupan Ikan. BPPT No.XL V/1991. Jakarta.

22. Rani, A, et al. 2010. Sebaran and Keragaman Ikan Karang di Pulau Barranglompo Kaitannya dengan Kondisi and Kompleksitas Habitat. Jurusan IImu Kelautan, Fakultas Ilmu Kelautan and Perikanan Unhas Makassar. Prosiding Seminar Nasional Biologi and Pembelajaran Biologi Biodiversitas Kepulauan Maluku and Pemanfaatannya dalam menunjang Pembelajaran Biologi Tahun 2017.

23. Rifa'i, M.A (2016). The Abundance and Size of Giant Sea Anemones at different Depths in the waters of Teluk Tamiang Village. South Kalimantan. AACL Bioflux 9(3): 704-712.

24. Rifa'i, M.A., Fatmawati, Tony, F., Kudsiah, H (2016). The Survival and Growth Rate of Three Species of Sea Anemones from Asexsual Reproduction in Pulau Kerumputan and Pulau Karayaan. Indonesia. EEC 22(3): 1523-1531.

25. Sekerci Y, Petrovskii S. 2015. Mathematical modelling of plankton oxygen dynamics under climate change. Bull Math Biol 77: 23252353.

26. Smyth K, Elliott M. 2016. Effects of changing salinity on the ecology of the marine environment. In: Solan M, Whiteley NM (eds). Stressors in The Marine EnvironmentChapter 9. Oxford University Press, Oxford.

27. Sahril A, 2017. Analysis of Dissolved Oxygen Parameters in Southern Ocean Island Waters as an Indicator of Pollution in Kotabaru District. [Research Report] Lambung Mangkurat University, Banjarbaru. [Indonesian]

28. Tony, F., Soemarno, Wiadnya, D, G, R., Hakim, L. 2020., Diversity of reef fish in Halang Melingkau Island, South Kalimantan, Indonesia., Biodiversitas ISSN: 1412-033X Volume 21, Number 10, October 2020 E-ISSN: 2085-4722, Pages: 4804-4812

29. Yusuf M, Handoyo G, Muslim, Wulandari SY, Setiyono H. 2012. Karakteristik Pola Arus Dalam Kitannya Dengan Kondisi Kulaitas Perairan and Kelimpahan Fitoplankton Diperairan kawasan Taman Nasional Laut Nasional Laut Karimunjawa. Buletin Oseonografi Marina. FPIK. Universitas Diponegoro. Semarang. 